\title{
Cortisol increases growth hormone-receptor expression in human osteoblast-like cells
}

\section{Swolin-Eide, A Nilsson ${ }^{1}$ and C Ohlsson}

Research Center for Endocrinology and Metabolism, Department of Internal Medicine and ${ }^{1}$ Department of Hand Surgery, Sahlgrenska University Hospital, S-413 45 Göteborg, Sweden

(Requests for offprints should be addressed to D Swolin-Eide, Research Center for Endocrinology and Metabolism, Department of Internal Medicine, Sahlgrenska Hospital, S-413 45 Göteborg, Sweden)

\begin{abstract}
It is well known that high levels of glucocorticoids cause osteoporosis and that physiologic levels of growth hormone $(\mathrm{GH})$ are required for normal bone remodeling. It has been suggested that glucocorticoids regulate $\mathrm{GH}$-responses via the regulation of GH-receptor expression. The aim of the present study was to investigate whether cortisol plays a role in the regulation of GH-receptor expression in cultured human osteoblasts.

The effect of serum starvation and cortisol on GHreceptor expression was tested in human osteoblast (hOB)like cells. Serum starvation for $24 \mathrm{~h}$ resulted in an increase in GH-receptor mRNA levels $(90 \pm 1 \%$ over control culture). Cortisol increased GH-receptor mRNA levels
\end{abstract}

in a dose-dependent manner with a maximal effect at $10^{-6} \mathrm{M}$. The stimulating effect of cortisol on $\mathrm{GH}-$ receptor mRNA levels was time-dependent, reaching a peak $12 \mathrm{~h}$ after the addition of cortisol $(126 \pm 29 \%$ over control culture) and remaining up to $12 \mathrm{~h}$ later. The increase in GH-receptor mRNA levels was accompanied by an increase in ${ }^{125} \mathrm{I}-\mathrm{GH}$ binding which reached a maximum at $24 \mathrm{~h}(196 \pm 87 \%$ over control culture).

In conclusion, glucocorticoids increase GH-receptor expression in hOB-like cells. Further studies are needed to clarify whether glucocorticoid-induced regulation of the GH-receptor is important in human bone physiology.

Journal of Endocrinology (1998) 156, 99-105

\section{Introduction}

Bone metabolism is regulated by a balance between bone resorption, caused by osteoclasts, and bone formation caused by osteoblasts. Clinical and experimental studies have demonstrated that growth hormone (GH) is important in normal bone remodeling. Patients with GHdeficiency have a decreased bone mineral density (Rosén et al. 1993) which can be reversed by long-term treatment with GH (Saggese et al. 1993, Rosén et al. 1994). Furthermore, GH enhances bone turnover in young healthy male volunteers as well as in osteopenic postmenopausal women (Brixen et al. 1990, 1995). The mechanism for the stimulating effect of $\mathrm{GH}$ on the amount of bone is not fully understood. We and others have demonstrated that human osteoblast (hOB)-like cells express functional $\mathrm{GH}$-receptors and that $\mathrm{GH}$ exerts an anabolic effect on the osteoblasts (Kassem et al. 1993, Morel et al. 1993, Nilsson et al. 1995). This indicates a direct stimulating effect of $\mathrm{GH}$ on bone formation.

Experimental studies have demonstrated that high concentrations of glucocorticoids result in a decrease in bone cell replication and collagen synthesis in calvarial explants (Canalis 1983). The mechanism for this inhibitory effect is not fully understood. Children with growth failure due to chronic glucocorticoid therapy have normal GH levels indicating the possibility of some degree of end organ insensitivity to GH (Robinson et al. 1995). It has therefore been suggested that glucocorticoids influence bone metabolism via a modulation of different components of the GH/insulin-like growth factor-I (IGF-I) system. Glucocorticoids decrease IGF-I expression in rat (McCarthy et al. 1990) and human osteoblasts (Swolin et al. 1996). Furthermore, several IGF-binding proteins (IGFBPs) which are known to modulate the bioactivity of IGF-I, are regulated by glucocorticoids. IGFBPs $-3,-4$ and -5 are decreased (Okazaki et al. 1994) while IGFBP-6 (Gabbitas \& Canalis 1996) is increased by glucocorticoids in osteoblast cultures.

Glucocorticoids may also interact with the GH/IGF-I axis via a regulation of $\mathrm{GH}-$ receptor expression. Conflicting in vivo as well as in vitro results have been presented regarding the effects of glucocorticoids on GH-receptor expression. Glucocorticoids increase GH-receptor mRNA levels in the liver and in the growth plate of rabbits (Heinrichs et al. 1994) while they decrease GH-receptor mRNA levels in rat liver (Gabrielsson et al. 1995, Bennett et al. 1996). Glucocorticoids also increase the GH-binding 
capacity of cultured rat osteosarcoma cells (Salles et al. 1994), rat pancreatic islet cells (Moldrup et al. 1993) and rat hepatocytes (Niimi et al. 1991). In contrast, King \& Carter-Su (1995) demonstrated that glucocorticoids decrease GH binding to a mouse fibroblast cell line.

The interaction of $\mathrm{GH}$ and glucocorticoids in the regulation of human bone metabolism has not yet been fully investigated. The present study was therefore undertaken to investigate the effects of glucocorticoids on $\mathrm{GH}-$ receptor expression in hOB-like cells.

\section{Materials and Methods}

\section{Cell culture}

Cultured hOB-cells were isolated from trabecular bone by orthopedic surgery as previously described (MacDonald et al. 1984, Nilsson et al. 1995). The bone explants were minced into small bonechips, washed extensively in Dulbecco's modified Eagle's medium (DMEM)/F12 1:1 (Gibco, Paisley, Scotland, UK) and then transferred into either 75 or $162 \mathrm{~cm}^{2}$ culture flasks (Costar, Cambridge, MA, USA). Cells were cultured in DMEM/F12, 1:1 with $10 \% \mathrm{v} / \mathrm{v}$ fetal calf serum (FCS; Gibco), fungizone $(500 \mu \mathrm{g} / \mathrm{l}$; Gibco), gentamycin sulfate $(50 \mathrm{mg} / \mathrm{l}$; Sigma, St Louis, MO, USA), L-glutamine ( $2 \mathrm{mmol} / \mathrm{l}$; Gibco), L-ascorbic acid (100 mg/l; Merck, KGaA, Darmstadt, Germany), in a humidified 5\% $\mathrm{CO}_{2}: 95 \% \mathrm{O}_{2}$ atmosphere at $37{ }^{\circ} \mathrm{C}$. Before the addition of hormone, cells were starved for various hours in DMEM (without phenol red (Gibco)) with $0 \cdot 5 \%$ dextran-coated charcoal-stripped FCS (kindly provided by M Slootweg, The Netherlands). Cortisol (hydrocortisone, H-0135, Lot 44H9402 $+41 \mathrm{H} 9409+115 \mathrm{H} 4629)$ was first diluted in $99.5 \%$ ethanol and then further diluted in DMEM (without phenol red (Gibco)). The study was approved by the Ethical Committee of Sahlgrenska University Hospital in Göteborg.

\section{Preparation of nucleic acid}

Total nucleic acids (TNA) were prepared according to the protocol described by Durnam \& Palmiter (1983). RNA was isolated according to the method described by Chomczynski \& Sacchi (1987).

\section{GH-receptor probe}

A $500 \mathrm{bp}$ fragment of exon 10 of the human $\mathrm{GH}(\mathrm{hGH})$ receptor gene (Nilsson et al. 1995) was used for the measurement of GH-receptor mRNA levels in hOB-like cells. ${ }^{35} \mathrm{~S}$-labeled hGH-receptor antisense RNA probe was generated with $\mathrm{Sp} 6$ polymerase from an EcoRI linearized PGEM-7Z(+) plasmid. The hGH-receptor sense RNA probe was generated with $\mathrm{T} 7$ polymerase from a BamHI linearized plasmid.
RNase protection solution hybridization assay

Total nucleic acids (TNA) were prepared by homogenizing harvested cells with a polytrone in a buffer containing $1 \%(\mathrm{w} / \mathrm{v})$ SDS, $20 \mathrm{mM}$ Tris- $\mathrm{HCl}(\mathrm{pH} 7.5)$ and $4 \mathrm{mM}$ EDTA. The homogenized cells were digested by an overnight proteinase- $\mathrm{K}$ treatment and total nucleic acids were prepared by subsequent phenol-chloroform extraction, according to the method described by Durnam \& Palmiter (1983). The RNase protection solution hybridization assay was carried out according to the protocol described by Mathews et al. (1986). Protected RNARNA hybrids were precipitated with trichloroacetic acid, collected on glass fiber filters and counted in a scintillation counter. The signal was compared with a standard curve obtained by hybridization to known amounts of $\mathrm{GH}-$ receptor mRNA. The intra-assay coefficient of variation for the hGH-receptor assays was less than $10 \%$ in the range of 50-2500 amol RNA standard. The results were correlated to the DNA content measured according to the method of Labarca \& Paigen (1980).

\section{RNase protection assay}

For the RNase protection assay followed by gel separation (RPA II kit, Ambion, Austin, TX, USA), $25 \mu \mathrm{g}$ total cellular RNA were hybridized at $45^{\circ} \mathrm{C}$ overnight with an ${ }^{35}$ S-labeled hGH-receptor riboprobe and then digested with RNase. The RNA-RNA hybrids were precipitated, re-suspended and separated on a 6\% TBE-urea gel (Novex, San Diego, CA, USA). Signals from protected fragments were quantified using a PhosphorImager (Molecular Dynamics, Sunnyvale, CA, USA).

\section{Binding studies \\ ${ }^{125}$ I-hGH (I-125-013, Batch: XS 4208, XS 4325, Euro-} Diagnostica, Malmö, Sweden) was repurified by gel filtration on a Sephadex G75 column equilibrated and eluted with phosphate buffer $(0.05 \mathrm{~mol} / \mathrm{l})$ and $1 \%(\mathrm{w} / \mathrm{v})$ BSA (Sigma). The cells were starved in 24-well dishes (Costar) for 10 to $12 \mathrm{~h}$ before the addition of cortisol, and were then preincubated at room temperature for $1 \mathrm{~h}$ with PBS supplemented with $1 \%(\mathrm{w} / \mathrm{v})$ BSA. The liquid was discarded and labeled tracer added (100 000 c.p.m./ml) in PBS supplemented with $0 \cdot 1 \%(\mathrm{w} / \mathrm{v})$ BSA, incubated for $4 \mathrm{~h}$ at $24^{\circ} \mathrm{C}$. The incubation was terminated by washing the cells three times in ice cold PBS at $4{ }^{\circ} \mathrm{C}$. Cells were solubilized in $2 \times 125 \mu \mathrm{l} \mathrm{NaOH}(1 \mathrm{M})$ and counted in a gammacounter (LKB 1277 Gammamaster, Sweden). All calculations were carried out in quadruplicate.

\section{Statistical procedure}

Values are given as means \pm S.E.M. Statistical evaluations of the data were carried out using Student's $t$-test for unpaired and paired samples. 
Table $1 \mathrm{hGH}$-receptor mRNA levels after different times of starvation in serum-free medium. Cells were cultured as described in Materials and Methods. Levels are expressed as fg/ $\mu \mathrm{g}$ DNA. Three different experiments were performed. Experiments were performed using cells from one patient. Values from the three different patients (male, 8 years old and females, 51 and 71 years old) were then pooled and are given as means \pm S.E.M. vs control cells (cells grown in 10\% FCS)

\begin{tabular}{|c|c|}
\hline & 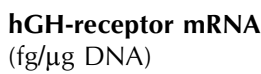 \\
\hline \multicolumn{2}{|c|}{ Starvation time $(\mathrm{h})$} \\
\hline 0 & $70 \cdot 0 \pm 14 \cdot 5$ \\
\hline 10 & $104 \cdot 7 \pm 25 \cdot 2$ \\
\hline 24 & $133 \cdot 0 \pm 0 \cdot 6^{*}$ \\
\hline
\end{tabular}

\section{Results}

No obvious correlation between GH-receptor mRNA levels and age or sex was found in hOB-cell preparations from different patients $(13$ males between 0.5 and 75 years of age and 12 females between 12 and 86 years of age; data not shown). Serum starvation of hOB-cells resulted in an increase in GH-receptor mRNA levels (Table 1). The effect on GH-receptor mRNA levels of some substances, previously shown to increase GH-receptor expression in cultured cells from rodents, were tested in hOB-like cells. Cortisol $\left(10^{-6} \mathrm{M}\right)$ increased $\mathrm{GH}$-receptor mRNA levels by $85.5 \%$ and in a dose-dependent manner, while no significant effect was observed with retinoic acid $\left(10^{-6} \mathrm{M}\right)$ or $\mathrm{GH}(5-100 \mathrm{ng} / \mathrm{ml}$; Fig. 1). The maximum effect of cortisol was found at $10^{-6} \mathrm{M}$ (Figs 2 and 3). The stimulating effect of cortisol on GH-receptor mRNA levels was time-dependent, reaching a peak $12 \mathrm{~h}$ after the addition of cortisol (control, $81 \pm 5 \mathrm{fg} / \mu \mathrm{g}$ DNA, $12 \mathrm{~h}$, $183 \pm 22 \mathrm{fg} / \mu \mathrm{g}$ DNA) and remaining up to $12 \mathrm{~h}$ later (Fig. 4). To investigate the specificity of the GH-receptor probe used in the RNase-protection solution hybridization assay, RNase-protected probe fragments were analyzed on denaturing polyacrylamide gels. A protected fragment of expected size $(500 \mathrm{bp})$ was detected in the mRNA from hOB-cells (Fig. 3).

Cortisol $\left(10^{-6} \mathrm{M}\right)$ was tested in binding studies using ${ }^{125} \mathrm{I}-\mathrm{GH}$. The cortisol-induced increase in GH-receptor mRNA levels was accompanied by an increase in ${ }^{125} \mathrm{I}-\mathrm{GH}$ binding in a time-dependent manner. Cortisol-induced ${ }^{125} \mathrm{I}-\mathrm{GH}$ binding appeared after $14 \mathrm{~h}$, reaching a maximum at $24 \mathrm{~h}(196 \pm 87 \%$ over control $)$ and remaining up to $17 \mathrm{~h}$ later (Fig. 5).

\section{Discussion}

Cushing (1932) showed that increased levels of glucocorticoids cause osteoporosis and increase the risk of bone fractures. Osteoblasts express receptors for glucocorticoids and high levels of glucocorticoids decrease the proliferation

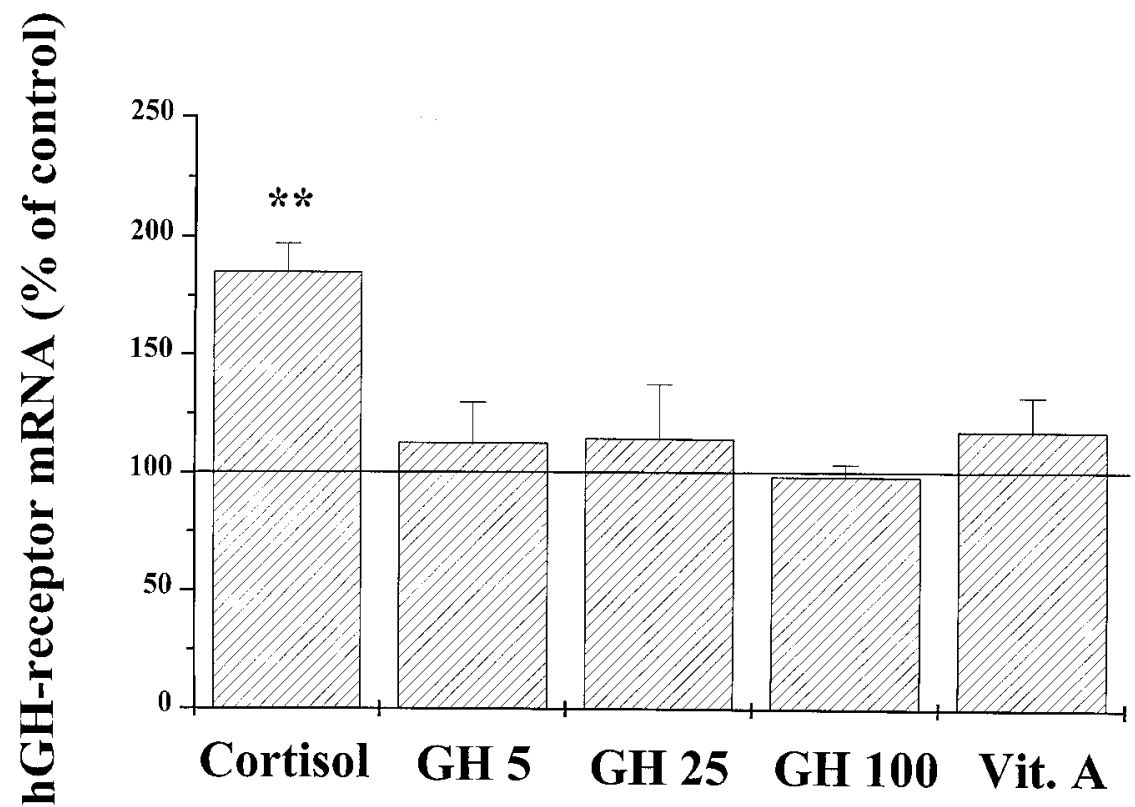

Figure 1 The effect of cortisol $(1 \mu \mathrm{M}), \mathrm{GH}(5,25$ and $100 \mathrm{ng} / \mathrm{ml})$ and retinoic acid (vitamin A) $(1 \mu \mathrm{M})$ on $\mathrm{GH}$-receptor mRNA levels in hOB-cells. Cells were cultured as described in Materials and Methods, starved for $30 \mathrm{~h}$ and stimulated with cortisol, $\mathrm{GH}$ or retinoic acid $16 \mathrm{~h}$ before cell harvest. Levels of GH-receptor mRNA are expressed as \% of control (horizontal line at $100 \%)$. Values are means \pm S.E.M. of four pooled patients. ${ }^{*} P<0 \cdot 01$ vs control. 


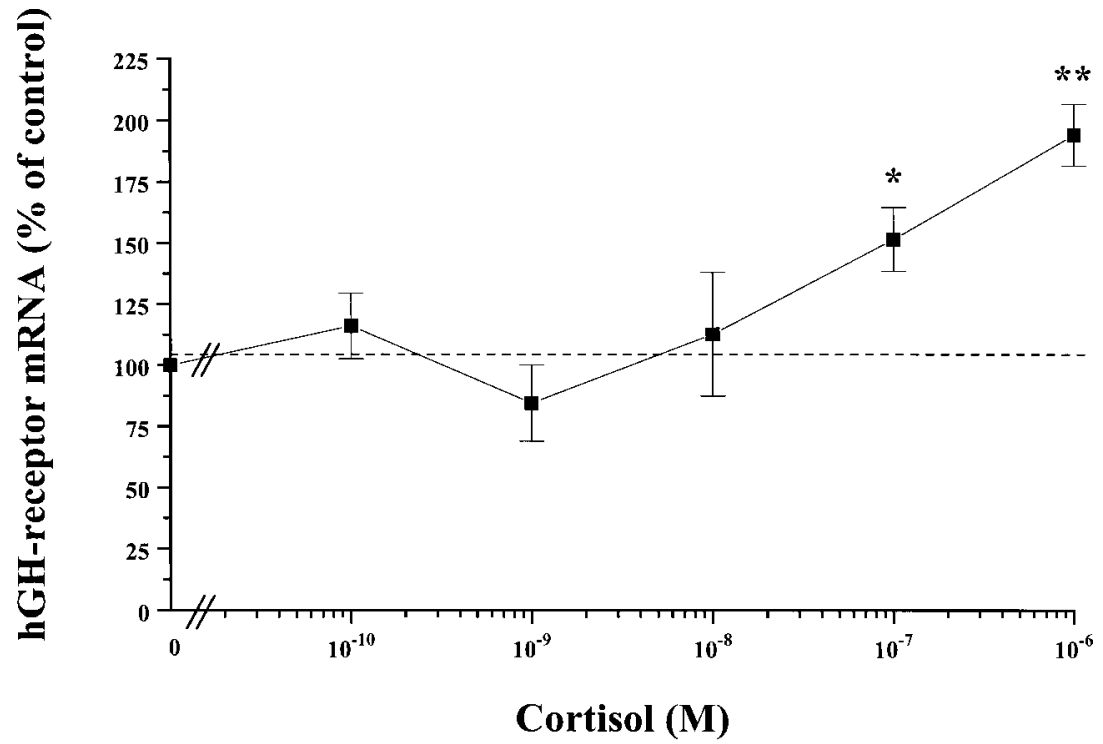

Figure 2 The dose-response effect of cortisol on GH-receptor mRNA levels in cultured hOB-cells. Cells were cultured as described in Materials and Methods, starved for $30 \mathrm{~h}$ and stimulated with different doses of cortisol $16 \mathrm{~h}$ before cell harvest. Levels of $\mathrm{GH}$-receptor mRNA are expressed as \% of control. Values are means \pm S.E.M. of five pooled patients (males, 18, 29 and 38 years old and females, 12 and 68 years old). ${ }^{*} P<0.05$ vs control, ${ }^{* *} P<0 \cdot 01$ vs control.

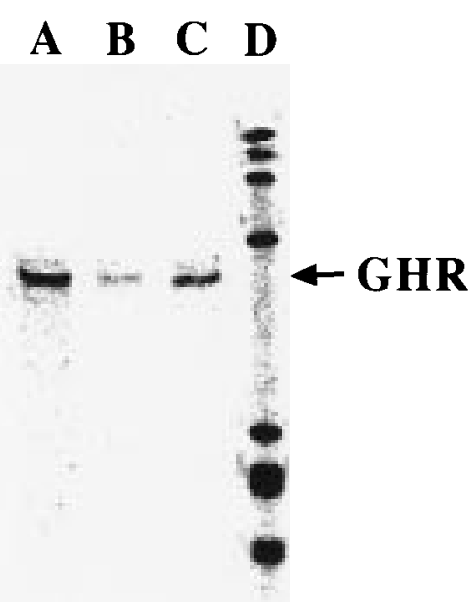

Figure 3 RNase-protected hGH-receptor (GHR) mRNA (500 bp) from hOB-cells (female, 15 years old), was analyzed by polyacrylamide gel electrophoresis. Cells were cultured as described in Materials and Methods, starved for $24 \mathrm{~h}$ and stimulated with cortisol $\left(10^{-6}\right.$ M) 16 h before cell harvest. (A) Standard 0.003 ng; (B) unstimulated hOB-cells; (C) cortisolstimulated hOB-cells; (D) Hae III ladder, for size detection.

and expression of differentiation markers in cultures of osteoblasts (Canalis \& Avioli 1992, Jonsson et al. 1993, Delany et al. 1995), demonstrating the direct effect of glucocorticoids on osteoblasts (Chen \& Feldman 1979).
The present study investigated whether glucocorticoids interact with GH-receptor expression in hOB-like cells.

Our results showing that serum starvation increases GH-receptor expression in hOB-like cells, are similar to those previously demonstrated in rat epiphyseal chondrocytes (Nilsson et al. 1990) and in osteosarcoma cells (Salles et al. 1994). GH and retinoic acid increase GH-receptor mRNA levels in cultured mouse and rat cells (Nilsson et al. 1990, Ohlsson et al. 1993, Slootweg et al. 1996). In contrast, in the present study using hOB-like cells, no significant effect of $\mathrm{GH}$ or retinoic acid was seen on GH-receptor mRNA levels, suggesting that regulation of the GH-receptor transcript may be species specific. It is also possible that the lack of any significant effect of $\mathrm{GH}$ on GH-receptor mRNA levels may be due to hOB-cells expressing fewer GH-receptors than in rat epiphyseal chondrocytes (Nilsson et al. 1990, 1995), or that primary hOB-cells are a heterogenous population of cells and/or due to a variation in patient samples.

We have, for the first time, demonstrated the effects of glucocorticoids on GH-receptor expression in human cells. Similar to in vivo results on the GH-receptor mRNA levels in the liver and growth plate of rabbits (Heinrichs et al. 1994), an increase in the GH-receptor mRNA levels was seen in hOB-like cells after treatment with glucocorticoids. This finding is in contrast to earlier results in vivo in rats in which glucocorticoids decreased the GH-receptor mRNA levels (Gabrielsson et al. 1995), indicating a species 


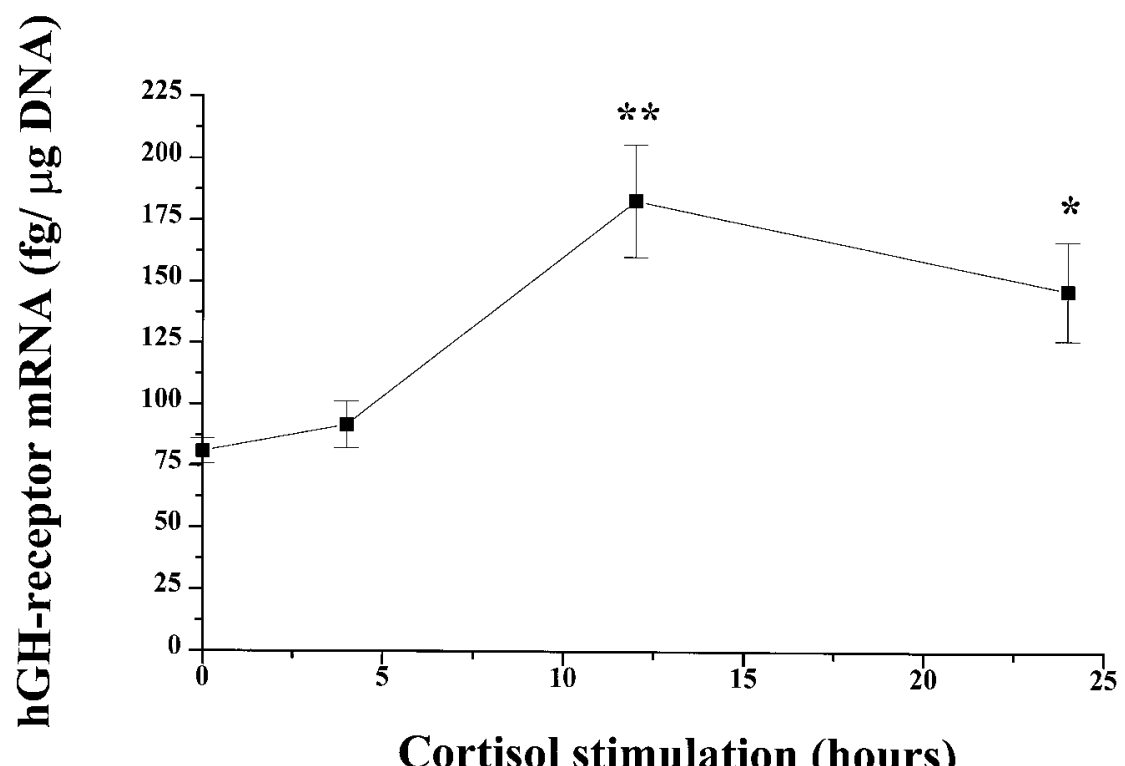

Figure 4 The time-dependent effect of cortisol on GH-receptor mRNA levels. Cells were cultured as described in Methods, starved for $30 \mathrm{~h}$ and stimulated with cortisol $\left(10^{-6} \mathrm{M}\right)$ at various times before cell harvest. Values are expressed as $f g / \mu g$ DNA, means \pm S.E.M. from four pooled patients (females, 12 and 29 years old; males, 41 and 55 years old). ${ }^{*} P<0 \cdot 05$, ${ }^{*} * P<0 \cdot 01$.

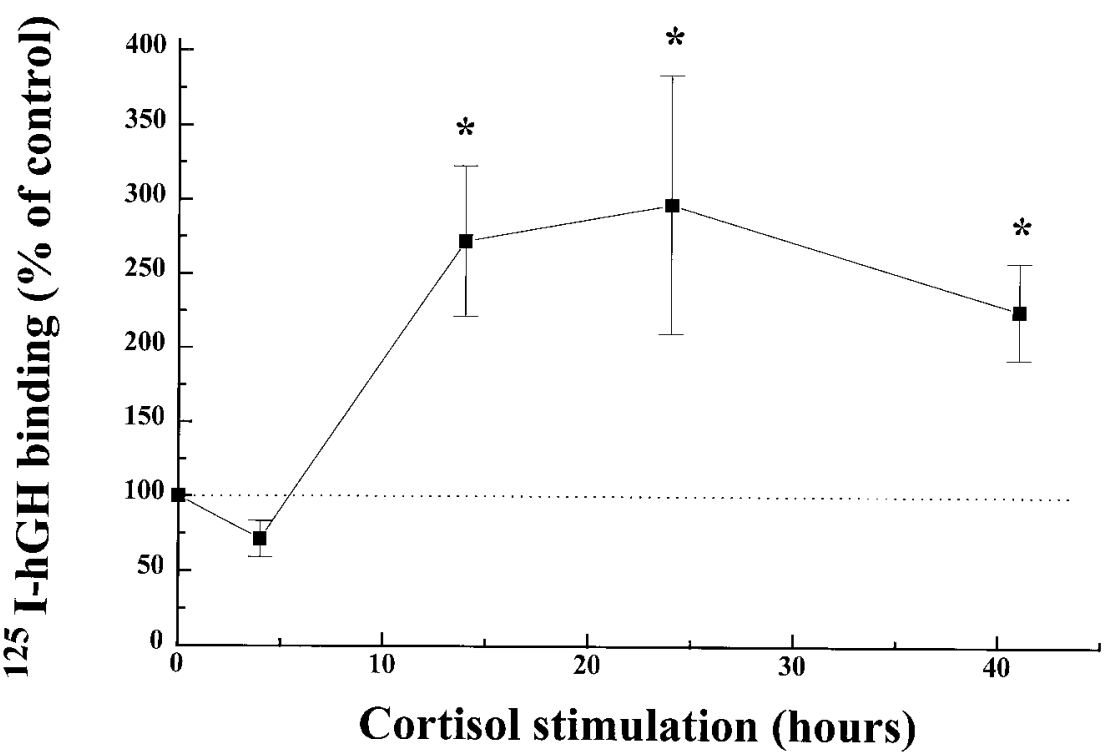

Figure 5 The time-dependent effect of cortisol $\left(10^{-6} \mathrm{M}\right)$ on ${ }^{125} \mathrm{I}-\mathrm{hGH}$ binding on hOB-cells. The time of starvation was $53 \mathrm{~h}$. Values are expressed as \% of control \pm S.E.M. from four pooled patients (females, 11 and 47 years old; males, 26 and 29 years old). ${ }^{*} P<0 \cdot 05$ vs untreated cells.

difference in the regulation of GH-receptor expression. This species difference in the expression and regulation of the GH-receptor and its soluble extracellular part (GHBP) is supported by the finding that GHBP in rabbits and humans is synthesized via a proteolytic cleavage of the extracellular part of the GH-receptor, while in rodents it is synthesized via alternative splicing from a separate mRNA transcript.

We and others have previously shown that glucocorticoids decrease IGF-I expression in osteoblasts. 
Furthermore, IGF-I down-regulates the GH-receptor expression in a local negative feedback loop (Slootweg et al. 1995, Leung et al. 1996). Therefore, the cortisol-induced increase in $\mathrm{GH}$-receptor expression may be due to a decrease in IGF-I expression leading to a reduced negative feedback on GH-receptor expression.

The conflicting effects of glucocorticoids on the GHreceptor mRNA levels may also be explained by the tissue-specific effects of glucocorticoids on GH-receptor expression. This possibility is supported by the finding that the first exon in the GH-receptor transcript is untranslated (5'UTR) and that there are several alternative exon 1 variants, which may be more-or-less tissue specific (Robinson et al. 1995). Thus, the different GH-receptor transcripts may be regulated in different ways. The hGHreceptor probe, used in the present study, recognizes a translated part of the GH-receptor mRNA corresponding to the intracellular part of the GH-receptor. This sequence of the GH-receptor is found in all known variants of mRNAs coding for the hGH-receptor. It is therefore interesting to see if glucocorticoids regulate $\mathrm{GH}$-receptor expression in other human cells.

Whereas conflicting results have been presented regarding the effect of glucocorticoids on GH-receptor expression, more consistent results have been presented regarding the inhibitory effects of glucocorticoids on GH-induced cell proliferation and the activation of different components of the GH-receptor signaling cascade (Salles et al. 1994, King \& Carter-Su 1995). Salles et al. (1994) found that cortisol increased GH-binding and reduced GH-induced cell proliferation in rat osteosarcoma cells. In contrast, King \& Carter-Su (1995) found reduced GH-binding and decreased early events in GH-signaling in glucocorticoidtreated mouse fibroblasts. It has been suggested that the contrasting effects of glucocorticoids on GH-binding may be explained by methodological differences in the conditions of the GH-binding (King \& Carter-Su 1995). In the study using rat osteosarcoma cells (Salles et al. 1994), binding studies were carried out with ${ }^{125} \mathrm{I}-\mathrm{GH}$ at room temperature for $24 \mathrm{~h}$, while in the study using mouse fibroblasts, binding was performed overnight at $4{ }^{\circ} \mathrm{C}$ (King \& Carter-Su 1995). A prolonged binding study at room temperature may lead to the internalization of some amount of tracer, making it difficult to distinguish whether binding to cell surface receptors or receptor turnover are being measured. In the present study, binding studies were performed with short duration $(4 \mathrm{~h})$ in order to minimize the amount of internalized tracer. However, binding studies were carried out at room temperature since $\mathrm{GH}-$ binding to human osteoblasts is difficult to measure at $4{ }^{\circ} \mathrm{C}$. In summary, the conflicting results of the effect of glucocorticoids on GH-receptor mRNA levels and ${ }^{125} \mathrm{I}-\mathrm{GH}-$ binding in different studies may be explained by species and tissue differences and/or different methodologies.

It is generally believed that high levels of glucocorticoids cause osteoporosis and GH-insensitivity. Furthermore,
GH exerts anabolic effects on osteoblasts (Slootweg et al. 1988, Nilsson et al. 1995). Thus, our finding that cortisol increases GH-receptor expression in osteoblasts could appear contradictory. However, cortisol may block GH effects at a post-receptor level, resulting in a secondary increase in GH-receptor expression. This hypothesis is supported by the finding that in rat osteosarcoma cells glucocorticoids increase GH-binding while GH-effects are decreased (Salles et al. 1994). Alternatively, it is possible that short-term stimulation with glucocorticoids in vitro is not an optimal model for studying the mechanism of action for glucocorticoid-induced GH-insensitivity in vivo.

In conclusion, glucocorticoids increase GH-receptor expression in hOB-like cells. Further studies are needed to clarify whether glucocorticoid-induced regulation of the $\mathrm{GH}-$ receptor is important in human bone physiology.

\section{Acknowledgements}

This work was supported by grants K95-19P-11328-01A and K96-19P11837-01A from the Swedish Medical Research Council, grants from Pharmacia Upjohn (Stockholm, Sweden) and Novo Nordisk Foundation (Bagsvaerd, Denmark), The Göteborg Medical Society, Swedish Society for Medical Research and the Lundberg Foundation. We wish to thank C Révérend and A Hansevi for excellent technical assistance. We would also like to thank the Department of Orthopedics, Sahlgrenska University Hospital.

\section{References}

Bennett PA, Levy A, Carmignac DF, Robinson IC \& Lightman SL 1996 Differential regulation of the growth hormone receptor gene: effects of dexamethasone and estradiol. Endocrinology 137 3891-3896.

Brixen K, Nielsen HK, Mosekilde L \& Flyvbjerg A 1990 A short course of recombinant human growth hormone treatment stimulates osteoblasts and activates bone remodeling in normal human volunteers. Journal of Bone and Mineral Research 5 609-618.

Brixen K, Kassem M, Nielsen HK, Loft AG, Flyvbjerg A \& Mosekilde L 1995 Short-term treatment with growth hormone stimulates osteoblastic and osteoclastic activity in osteopenic postmenopausal women: a dose-response study. Journal of Bone and Mineral Research 10 1865-1874.

Canalis E 1983 Effect of glucocorticoids on type I collagen synthesis, alkaline phosphatase activity and deoxyribonucleic acid content in cultured rat calvariae. Endocrinology 112 931-939.

Canalis E \& Avioli L 1992 Effects of deflazacort on aspects of bone formation in cultures of intact calvariae and osteoblast-enriched cells. Journal of Bone and Mineral Research 7 1085-1092.

Chen T \& Feldman D 1979 Glucocorticoids: receptors and actions in subpopulations of cultured rat bone cells. Journal of Clinical Investigation 63 750-758.

Chomczynski P \& Sacchi N 1987 Single-step method of RNA isolation by acid guanidinium thiocyanate-phenol-chloroform extraction. Analytical Biochemistry 162 156-159.

Cushing H 1932 The basophil adenomas of the pituitary body and their clinical manifestations (pituitary basophilism). Bulletin of the Johns Hopkins Hospital 50 137-195. 
Delany A, Jeffrey J, Rydziel S \& Canalis E 1995 Cortisol increases interstitial collagenase expression in osteoblasts by posttranscriptional mechanisms. Journal of Biological Chemistry 270 26607-26612.

Durnam DM \& Palmiter RD 1983 A practical approach for quantitating specific mRNAs by solution hybridization. Analytical Biochemistry 131 385-393.

Gabbitas B \& Canalis E 1996 Cortisol enhances the transcription of insulin-like growth factor-binding protein-6 in cultured osteoblasts. Endocrinology 137 1687-1692.

Gabrielsson BG, Carmignac DF, Flavell DM \& Robinson ICAF 1995 Steroid regulation of growth hormone $(\mathrm{GH})$ receptor and $\mathrm{GH}-$ binding protein messenger ribonucleic acids in the rat. Endocrinology 136 209-217.

Heinrichs C, Yanovski JA, Roth AH, Yu YM, Domené HM, Yano K, Cutler GB \& Baron J 1994 Dexamethasone increases growth hormone receptor messenger ribonucleic acid levels in liver and in growth plate. Endocrinology 135 113-118.

Jonsson KB, Ljunghall S, Karlström O, Johansson AG, Mallmin H \& Ljunggren Ö 1993 Insulin-like growth factor I enhances the formation of type I collagen in hydrocortisone-treated human osteoblasts. Bioscience Reports 13 297-302.

Kassem M, Blum W, Ristelli J, Mosekilde L \& Eriksen EF 1993 Growth hormone stimulates proliferation and differentiation of normal human osteoblast-like cells in vitro. Calcified Tissue International 52 222-226.

King APJ \& Carter-Su C 1995 Dexamethasone-induced antagonism of growth hormone $(\mathrm{GH})$ action by down-regulation of $\mathrm{GH}$ binding in 3T3-F442A fibroblasts. Endocrinology 136 4796-4803.

Labarca C \& Paigen K 1980 A simple, rapid, and sensitive DNA assay procedure. Analytical Biochemistry 102 344-352.

Leung K, Rajkovic IA, Peters E, Markus I, Van Wyk JJ \& Ho KK 1996 Insulin-like growth factor I and insulin down-regulate growth hormone $(\mathrm{GH})$ receptors in rat osteoblasts: evidence for a peripheral feedback loop regulating GH action. Endocrinology 137 2694-2702.

McCarthy TL, Centrella M \& Canalis E 1990 Cortisol inhibits the synthesis of insulin-like growth factor-I in skeletal cells. Endocrinology 126 1569-1575.

MacDonald BR, Gallagher JA, Ahnfelt-Ronne I, Beresford JN, Gowen M \& Russel GG 1984 Effects of bovine parathyroid hormone and 1,25 dihydroxy vitamin $\mathrm{D}_{3}$ on the production of prostaglandins by cells derived from human bone. FEBS Letters 169 49-52.

Mathews LS, Norstedt G \& Palmiter RD 1986 Regulation of insulin-like growth factor I gene expression by growth hormone. Proceedings of the National Academy of Sciences of the USA $\mathbf{8 3}$ 9343-9347.

Moldrup A, Petersen ED \& Nielsen JG 1993 Effects of sex and pregnancy hormones on growth hormone and prolactin receptor gene expression in insulin-producing cells. Endocrinology 133 1165-1172.

Morel G, Chavassieux P, Barenton B, Dubois PM, Meunier PJ \& Boivin G 1993 Evidence for a direct effect of growth hormone on osteoblasts. Cell and Tissue Research 273 279-286.
Niimi S, Hayakawa T, Tanaka A \& Ichihara A 1991 Glucose regulation of growth hormone receptors in primary cultured rat hepatocytes. Endocrinology 129 2734-2739.

Nilsson A, Carlsson B, Mathews L \& Isaksson OG 1990 Growth hormone regulation of the growth hormone receptor mRNA in cultured rat epiphyseal chondrocytes. Molecular and Cellular Endocrinology 70 237-246.

Nilsson A, Swolin D, Enerbäck S \& Ohlsson C 1995 Expression of functional growth hormone receptors in cultured human osteoblast-like cells. Journal of Clinical Endocrinology and Metabolism 80 3483-3488.

Ohlsson C, Lövstedt K, Holmes PV, Nilsson A, Carlsson L \& Törnell J 1993 Embryonic stem cells express growth hormone receptors: regulation by retinoic acid. Endocrinology 133 2897-2903.

Okazaki R, Riggs BL \& Conover CA 1994 Glucocorticoid regulation of insulin-like growth factor-binding protein expression in normal human osteoblast-like cells. Endocrinology 134 126-132.

Robinson ICAF, Gabrielsson B, Klaus G, Mauras N, Holmberg C \& Mehls O 1995 Glucocorticoids and growth problems. Acta Paedriatrica 411 81-86.

Rosén T, Hansson T, Granhed H, Szucs J \& Bengtsson B- ̊ 1993 Reduced bone mineral content in adult patients with growth hormone deficiency. Acta Endocrinologica 129 201-206.

Rosén T, Johannsson G, Hallgren P, Caidahl K, Bosaeus I \& Bengtsson B- 1994 Beneficial effects of 12 months replacement therapy with recombinant human growth hormone to growth hormone deficient adults. Endocrinology and Metabolism 1 55-66.

Saggese G, Baroncelli GI, Bertelloni S, Cinquanta L \& Di Nero G 1993 Effects of long-term treatment with growth hormone on bone and mineral metabolism in children with growth hormone deficiency. Journal of Pediatrics 122 37-45.

Salles JP, De Vries CP, Netelenbos JC \& Slootweg MC 1994 Dexamethasone increases and serum decreases growth hormone receptor binding to UMR-106.01 rat osteosarcoma cells. Endocrinology 134 1455-1459.

Slootweg MC, van Buul-Offers SC \& Hermann-Erlee SA 1988 Direct stimulatory effect of growth hormone on DNA synthesis of fetal chicken osteoblasts in culture. Acta Endocrinologica 118 294-300.

Slootweg, MC, Ohlsson C, Salles JP, Vries CP \& Netelenbos JC 1995 Insulin-like growth factor binding proteins- 2 and -3 stimulate growth hormone receptor binding and mitogenesis in rat osteosarcoma cells. Endocrinology 136 4210-4217.

Slootweg MC, Salles JP, Ohlsson C, Vries CP, Engelbregt MJE \& Netelenbos JC 1996 Growth hormone binds to a single high affinity receptor site on mouse osteoblasts: modulation by retinoic acid and cell differentiation. Journal of Endocrinology 150 465-472

Swolin D, Brantsing C, Matejka G \& Ohlsson C 1996 Cortisol decreases IGF-I mRNA levels in human osteoblast-like cells. Journal of Endocrinology 149 397-403.

Received 20 June 1997

Accepted 13 August 1997 